\title{
INFLUENCE OF INTEGRATED TEAMS AND CO-LOCATION TO ACHIEVE THE TARGET COST IN BUILDING PROJECTS
}

\author{
Frederick M. Gutiérrez Lazarte ${ }^{1}$
}

\begin{abstract}
Construction projects are complex that the creation of value cannot only be carried out by a company; for this reason, temporary contracts are created between construction companies, designers, and owners. However, these contractual relationships are difficult when the interests and needs of each company are contrasted with those of the project and generate problems of collaboration between the parties. The present study describes the implementation of project integration practices such as co-location and integrated teams in a building project in Lima, Peru. The ideas proposed resulted in savings for the project. The study details the ideas by discipline and the achievements obtained.
\end{abstract}

\section{KEYWORDS}

Integration, Process, Transformation-Flow-Value, Target Cost, Integrated Project Delivery (IPD)

\section{INTRODUCTION}

Construction projects are complex in nature that the creation of value cannot only be carried out by a company, it is for this reason that temporary contracts are created between construction companies, designers and owners. However, these contractual relationships are difficult when the interests and needs of each company are contrasted with those of the project and generate problems of collaboration between the parties. To solve these kinds of problems, integration strategies and solutions have been proposed, such as involving the main participants of the project from early stages to develop the objectives of the project as a whole (Forgues, Koskela, and Lejeune, 2008; Reed et al., 2017). Within these solutions, many times the proposed way of working includes that project members who are part of different organizations share the same physical space (Kokkonen and Vaagaasar, 2018).

This variable "workspace" according to research is used to improve efficiency and reduce waste in Architecture, Engineering and Construction (AEC) projects revealing great advantages (Majava, Haapasalo, and Aaltonen, 2019). The collaboration that develops between organizations under the Integrated Project Delivery (IPD) model depends largely on the "big room" (Khanzode, Fischer, and Reed, 2007) or space of shared work, which requires the constant presence of almost all participants and is particularly difficult for small or medium-sized projects. For this reason, investigations

DBA student, CENTRUM PUCP Business School, Pontificia Universidad Católica del Perú, Lima, Perú, frederick.gutierrez@pucp.edu.pe, orcid.org/0000-0003-4559-276X 
have been developed that propose replacing this physical workspace with a virtual one (Dave, Pikas, Kerosuo, and Mäki, 2015; Ma, Zhang, and Li, 2018).

In this way, the present research seeks to describe how the use of integrated team that uses the same physical location as a workspace can generate design alternatives that, combined with appropriate cost estimation methods, can be beneficial for the projects of building.

\section{BACKGROUND}

During the last decade, companies and researchers have defended the need for value creation through collaboration between organizations (Le Pennec and Raufflet, 2018). However, the way companies are organized to develop a construction project is not ideal because of the well-known problems to achieve collaboration such as: poor communication, fragmented industry and adverse relationships (Nicolini, Holti, and Smalley, 2001).

There are models that propose that using collaborative design, requirements management, and collaborative spaces achieved a company with a better value proposition (Alhava et al., 2015). In addition solutions such as the location of the members of a project in collaborative spaces (co-location), can increase collaboration (Kokkonen and Vaagaasar, 2018; Tezel, Aziz, Koskela, and Tzortzopoulos, 2016). Also the integration of the teams and the achievement of collaboration is important to have a successful project that generates value and customer satisfaction (Choi, Yun, Leite, and Mulva, 2019; Lee, Tommelein, and Ballard, 2010; Forgues, Koskela, and Lejeune, 2008).

Furthermore, Hagedoorn, Lokshin and Zobel (2018) argue that diversity should be highlighted as an important factor in the characteristics of organizations and alliancebased projects. Therefore, the configuration of organizations should not be seen through a "one size fits all" approach. that this effect of diversity makes a high level of variety optimal in environments with greater modularity or a broader scope of knowledge distribution.

On the other hand, target costing is an effective management technique that has been used in manufacturing for decades to achieve cost predictability during new product development. The adoption of this technique promises benefits for the construction industry as it struggles to raise the number of successful outcomes and certainty of project delivery in terms of cost, quality, and time (Zimina, Ballard, and Pasquire, 2012). Kron and Von Der Haar (2016) analyzed the increasing values with target costing pertaining to an optimized cost-benefit-ratio for project development of office buildings. They indicated that target costing provides support for project developers in developing properties of increasing value.

\section{Research Problem}

The research problem focuses on how integrated team and the use of co-location can benefit in the achieve of target cost of a construction project in spite of companies having different interests (Smits and van Marrewijk, 2012). Getting organizations in a construction project to work collaboratively in an integrated team is a challenge. Projects based on partnerships of different companies require organizations in which all parties work together in good faith, share the risks of the project and make unanimous decisions to improve the project (Pargar, Kujala, Aaltonen, and Ruutu, 2019). 


\section{Research Purpose}

This research will have the following purpose: Describing the benefits of using integrated team and co-location in a construction project

\section{THEORETICAL FRAMEWORK}

According to the literature reviewed, there have been several investigations related to integrated teams or the integration of organizations in recent decades (Maslin-Prothero and Bennion, 2010). Many of these investigations have been oriented to the health sector, where there are a large number of specialties that interact for the care of a patient (Hudson, 2006). However, there is also literature on the use of the concept of integrated teams in project-based organizations such as companies in the construction industry (Fleming and Koppelman, 1996).

Team integration can be defined as a condition in which different disciplines or organizations with different objectives, needs and cultures merge into a single cohesive and mutually supportive unit (Baiden, Price, and Dainty, 2006) taking into account collaborative processes and cultures (Ochieng and Price, 2009). Integrated approaches require that individuals from various organizations work together to achieve common project objectives attainable through the exchange of information. This means that different company processes and organizational cultures must be aligned collaboratively (Baiden et al., 2006). For the present investigation integrated teams refers to the organization of different companies and different specialties working as a single cohesive team that seeks the collaboration and achievement of common objectives of a project.

Reviewing the literature about "collaborative workspaces" or "co-location" indicates that the theme has been developed since 2002 applied to projects. For example, Nicolini (2002) indicated that teams located in the same workspace is one of the important factors for the success of a project. Also a study by Hua, Loftness, Heerwagen, and Powell (2011) that indicate that the concept of collaborative space refers not only to a physical space that connects individuals but also to the practices of informal or formal collaboration within the space. For the present investigation collaborative workspaces (co-location) the process is defined as the process of placing the teams in a single shared physical space, where you can interact with all the members of a team.

The following are the main terms used in the investigation:

- Integrated teams: "A condition in which different organizations with different objectives, needs and cultures merge into a single cohesive and mutually supportive unit" (Baiden et al., 2006).

- Co-location "The collaborative execution of work by key members of the project team in a single shared physical location" (Fischer, 2017).

- Project delivery method: "It is the process by which the contractual relationships between the designer, builder and owner, the roles and responsibilities of the parties are established, as well as the sequence of activities required to deliver the project" (Konchar and Sanvido, 1998).

- Fragmentation: "Separation that exists between the different participants of the construction project, the design phase separated from the construction phase, in some cases separated from the part of the procurement or procurement of the project" (Baiden et al., 2006) 


\section{CASE STUDY}

\section{Project DesCRIPTION}

The project under study is a building project located in the city of Lima, Peru. The owner of the project is the company Edifica and assigned directly to the Construction Company called Produktiva as responsible for the construction and design management from the early stages of this. The project has 5 basements, 23 floors, an approximate covered area of $11,673 \mathrm{~m} 2$ and an approximate design period of 4 months and construction of 20.5 months.

The target cost allocated for the project will be kept confidential due to the investigation, however the investigation will be carried out on the gap between the assigned target cost and the first estimate of the cost of the project, the amount was more than 1 Million soles.

\section{METHOD}

The steps for implementation are shown $\mathrm{n}$ in Figure 1. These steps were suggested by a lean consultant. The model begins with a validation study where opportunities for improvement were identified through interviews with key participants in the project (designers, owner, contractor, providers) on the purpose that the knowledge of each participant can be collected. Then integrated teams are formed in a first session where the project owner and his representatives, the builder and his representatives and the designers and their representatives participate in a meeting. Together, the goals to be achieved in the project are raised.

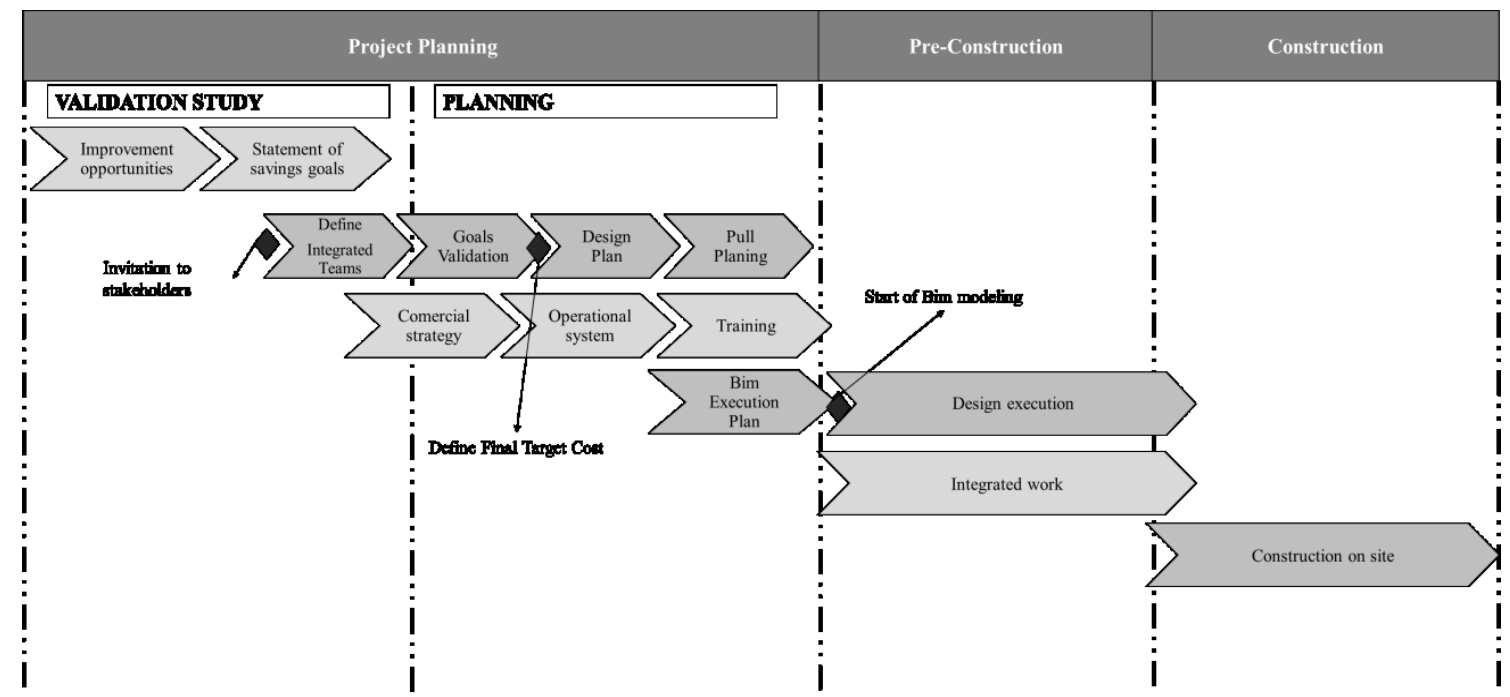

Figure 1: Implementation model where the use of integrated team is appreciated. The model was developed by a lean consultant. It was based on project integration practices

\section{RESULTS}

In the first stage after the interview with the participants of the project, the results shown in Table 1 were obtained, where the large number of ideas generated can be appreciated. After that phase the ideas were categorized and a list of nine categories was obtained that would serve in the future to form the integrated teams. The results of the categories can be seen in Table 2 . 
Table 1: Ideas from interviews with project participants

\begin{tabular}{|c|c|c|}
\hline Interviewed & Item & Proposed ideas to improvement opportunities \\
\hline \multirow[t]{5}{*}{$\begin{array}{l}\text { Structural } \\
\text { engineer }\end{array}$} & 1 & $\begin{array}{c}\text { Thickness reduction of anchored walls with larger plate in punching } \\
\text { area, for which it is convenient to define the subcontractor of } \\
\text { anchored walls }\end{array}$ \\
\hline & 2 & $\begin{array}{l}\text { Identify the basements of the neighbors to consider the true support } \\
\text { walls to consider in the project }\end{array}$ \\
\hline & 4 & $\begin{array}{c}\text { Use different concrete f'c. If using } 350 \mathrm{~kg} / \mathrm{cm} 2 \text { and } 280 \mathrm{~kg} / \mathrm{cm} 2 \\
\text { there would be no problem in the nodes, provided the difference is } \\
\text { not greater than } 70 \mathrm{~kg} / \mathrm{cm} 2\end{array}$ \\
\hline & 5 & $\begin{array}{l}\text { It is cheaper to use more resistant concrete and reduce steel. Costing } \\
\text { can be done after pre-sizing. }\end{array}$ \\
\hline & & Recommend using pre-cut steel. \\
\hline \multirow{13}{*}{$\begin{array}{l}\text { Electrical } \\
\text { Engineer } \\
\text { and Sanitary } \\
\text { Engineer }\end{array}$} & 6 & It is convenient that the boards are located close to the amount \\
\hline & $\begin{array}{l}7 \\
8\end{array}$ & $\begin{array}{l}\text { The depth of the boards must be } 8.5 \text { to } 9.0 \mathrm{~cm} \text { for which the wall } \\
\text { must be } 10 \mathrm{~cm}\end{array}$ \\
\hline & 9 & $\begin{array}{l}\text { The rule indicates that every } 3 \mathrm{~m} 2 \text { must have an outlet in bedrooms. } \\
\text { In Edifica they ask for } 2 \text { to } 3 \text { outlets per bedroom. }\end{array}$ \\
\hline & 10 & Deposit walls must be cleared in the plans. \\
\hline & 11 & Review proposal of points of light and outlets in basements \\
\hline & 12 & It is alert to define the need to use outlets in closets. \\
\hline & 13 & There are no water pipes in basements \\
\hline & 14 & There will only be a grid at the end of each ramp \\
\hline & 15 & Check the need for outlets with protectors in basements. \\
\hline & 16 & $\begin{array}{c}\text { Feasibility indicates that the meters must be located on Dean Valdivia } \\
\text { Street. }\end{array}$ \\
\hline & 17 & $\begin{array}{l}\text { It is convenient to seek approval in Architecture so that the walls of } \\
\text { the light meters can use } 1.8 \mathrm{~m} \text { in height. }\end{array}$ \\
\hline & 18 & $\begin{array}{c}\text { Check the load. The standard requires electric cooking and electric } \\
\text { hot water. }\end{array}$ \\
\hline & & Only one sinkhole will be used. \\
\hline \multirow[t]{4}{*}{$\begin{array}{l}\text { Builder } \\
\text { Engineer }\end{array}$} & $\begin{array}{l}19 \\
20\end{array}$ & $\begin{array}{l}\text { Basements smaller than five levels are more convenient to use pre- } \\
\text { slabs vs post-tensioned slabs. }\end{array}$ \\
\hline & 21 & Study alternative proposals for window systems with other suppliers. \\
\hline & 22 & $\begin{array}{c}\text { Study optimized design of melamine furniture with Ideoforma } \\
\text { Company }\end{array}$ \\
\hline & & Incorporate the pre-cut steel supplier in the design stage \\
\hline
\end{tabular}

Every proposed idea had to be reviewed to assess its feasibility. In addition to the main participants of the project; designer, builder and owners; Some subcontractors were added after analyze the proposed ideas to detail all the constraints of the process. For example, the slope stabilization subcontractor for anchored walls, the pre-cut structural steel supplier, the melamine furniture subcontractor, the glass and aluminium subcontractor and the pre-slabs subcontractor were included in the evaluation of the ideas feasibility. 
Table 2: Categories of the generated ideas through the first interview

\begin{tabular}{cc}
\hline Item & Categories of the generated ideas through the first interview \\
\hline 1 & Anchored walls \\
2 & Substructure and superstructure slabs \\
3 & Strength of concrete in vertical elements to reduce amount of steel \\
4 & Use of pre-assembled steel \\
5 & Fire walls \\
6 & Change of thickness in masonry walls \\
7 & Glass and aluminum \\
8 & Electrical outlets \\
9 & Melamine furniture \\
\hline
\end{tabular}

\section{INTEGRATED TEAMS}

Finally, seven integrated teams made up of 4 people on average and a nuclear team were formed as shown in Figure 2. The integrated teams were made up of the owner, the designer, the builder and the main subcontractors. The detail of the organization of each team can be seen in Table 3 . The organizational design was carried out taking into account the final product required according to the ideas initially proposed. According to this it was identified which were the specialties they contributed. In the case of the choice of subcontractors, a previous contest was held in which factors such as innovation, availability to work collaboratively, savings proposals, commercial proposals among others were evaluated. Finally, in Table 3 you can also see the goals achieved vs the initially planned goals.

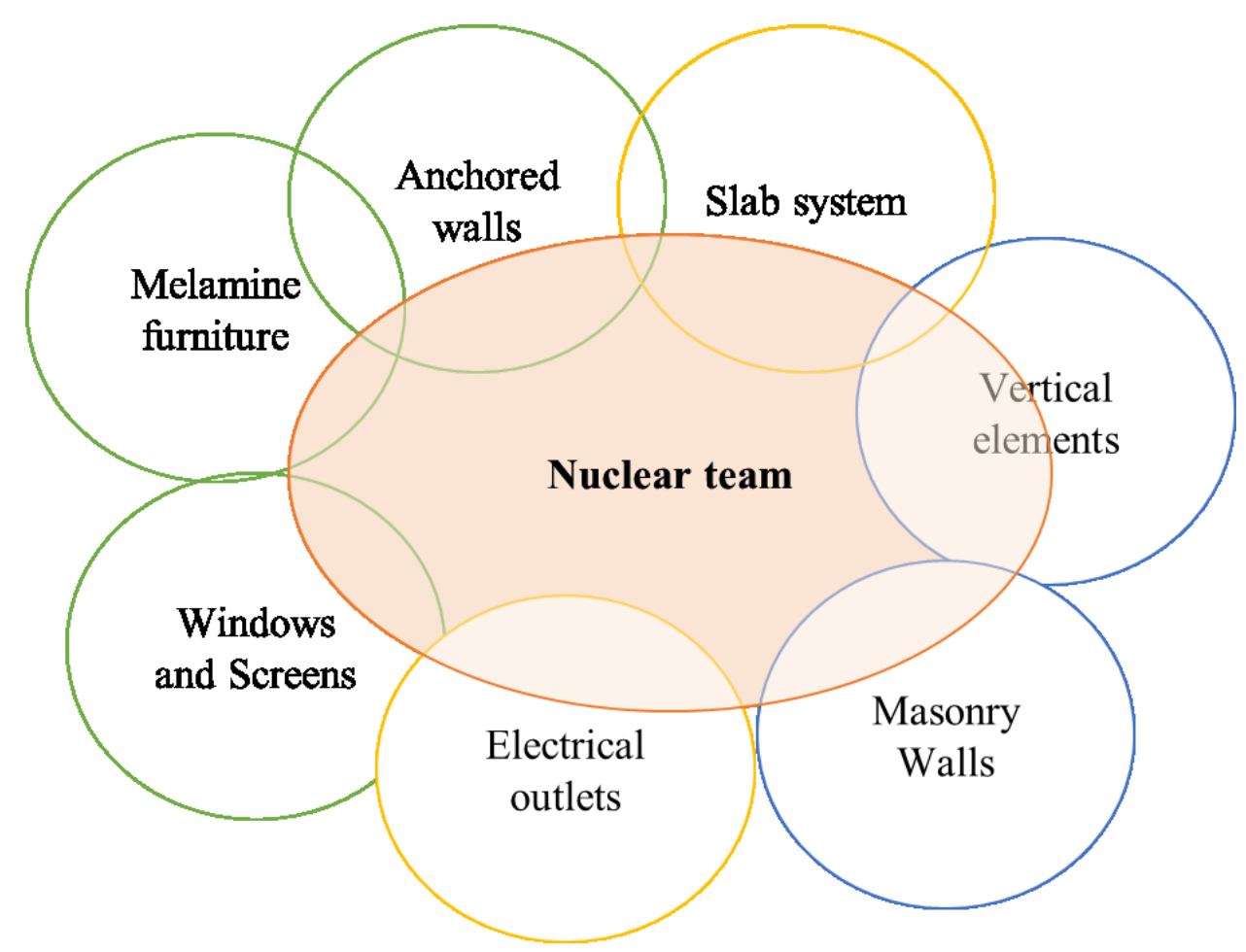

Figure 2: Structure of the integrated teams 
Table 3: Design of integrated teams, savings goals planned, and savings achieved in Peruvian soles exchange

\begin{tabular}{|c|c|c|c|c|}
\hline Item & $\begin{array}{l}\text { Integrated } \\
\text { Team }\end{array}$ & Organization & $\begin{array}{l}\text { Savings } \\
\text { goals } \\
\text { planned }\end{array}$ & $\begin{array}{l}\text { Savings } \\
\text { achieved }\end{array}$ \\
\hline IE1 & $\begin{array}{l}\text { Anchored } \\
\text { walls }\end{array}$ & $\begin{array}{l}\text { Structural engineer, builder, subcontractor } \\
\text { of anchored walls }\end{array}$ & 70,800 & 83,153 \\
\hline IE2 & Slab system & $\begin{array}{l}\text { Structural engineer, builder, pre-slabs } \\
\text { subcontractor, owner }\end{array}$ & 224,200 & 358,203 \\
\hline IE3 & $\begin{array}{l}\text { Vertical } \\
\text { elements }\end{array}$ & $\begin{array}{l}\text { Structural Engineer, Builder, Pre-Slab } \\
\text { Subcontractor, Pre-cut Steel Supplier }\end{array}$ & 88,500 & \\
\hline IE4 & $\begin{array}{l}\text { Masonry } \\
\text { Walls }\end{array}$ & $\begin{array}{c}\text { Structural engineer, architect, electrical } \\
\text { engineer, sanitary engineer, builder, } \\
\text { owner. }\end{array}$ & 153,400 & 147,205 \\
\hline IE5 & $\begin{array}{l}\text { Electrical } \\
\text { outlets }\end{array}$ & $\begin{array}{l}\text { Electrical engineer, structural engineer, } \\
\text { builder, owner }\end{array}$ & 59,000 & \\
\hline IE6 & $\begin{array}{l}\text { Windows and } \\
\text { Screens }\end{array}$ & $\begin{array}{l}\text { Architect, builder, owner, windows } \\
\text { subcontractor. }\end{array}$ & 212,400 & 324,872 \\
\hline \multirow[t]{2}{*}{ IE7 } & $\begin{array}{l}\text { Melamine } \\
\text { furniture }\end{array}$ & $\begin{array}{l}\text { Architect, builder, owner, melamine } \\
\text { furniture subcontractor }\end{array}$ & 224,200 & 89,029 \\
\hline & & TOTAL & $1,032,500$ & $1,002,462$ \\
\hline
\end{tabular}

\section{BIG ROOM OR I-ROOM}

The development of the implementation of integrated teams a co-location work was carried out in a large work room where initially a meeting was held where all the participants of the project were invited in a plenary session to explain the work model indicated in Figure 1. After this in the same work room 4 work teams were divided in the same room. Where the different integrated teams worked on the generation of knowledge and validation of the different ideas developed. In Figure 3 can be seen the outline of the workplace and the photos in Figure 4. This room is located in the district of Chorrillos, outside the office of all organizations that participate in. It is a comfortable workplace of modular infrastructure and capable of housing 4 integrated work teams at the same time each team with an interactive screen where plans and BIM models can be projected and reviewed. In addition to acrylic boards located on each wall. 

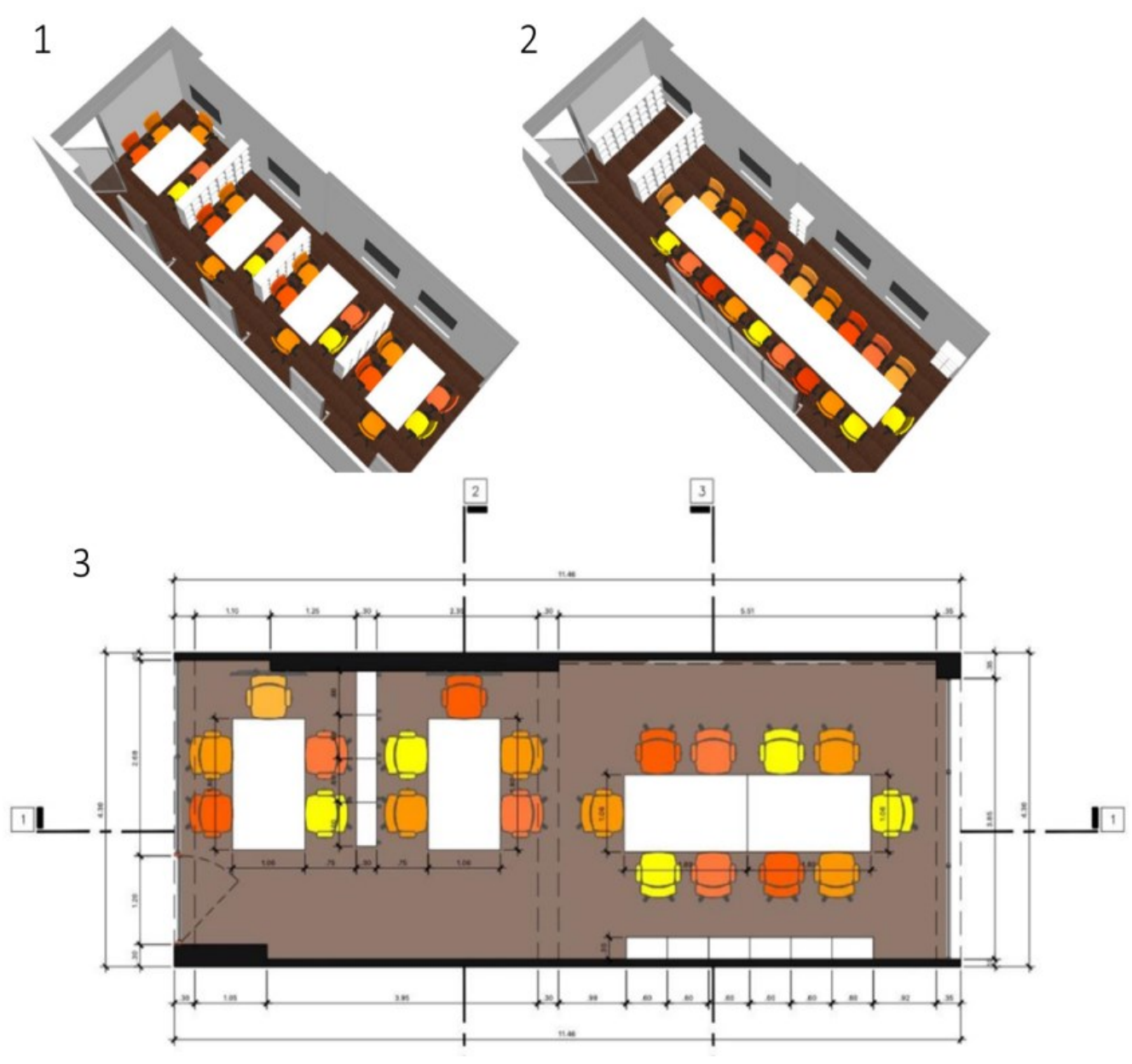

Figure 3: Big room where the work sessions of the integrated teams were held. In (1) The division of the room into 4 workstations can be seen.

In (2) you can see the same divided room for a plenary session with all participants. In (3) you can see the distribution plan. Each environment is equipped with interactive screens to review BIM models and review different alternatives.
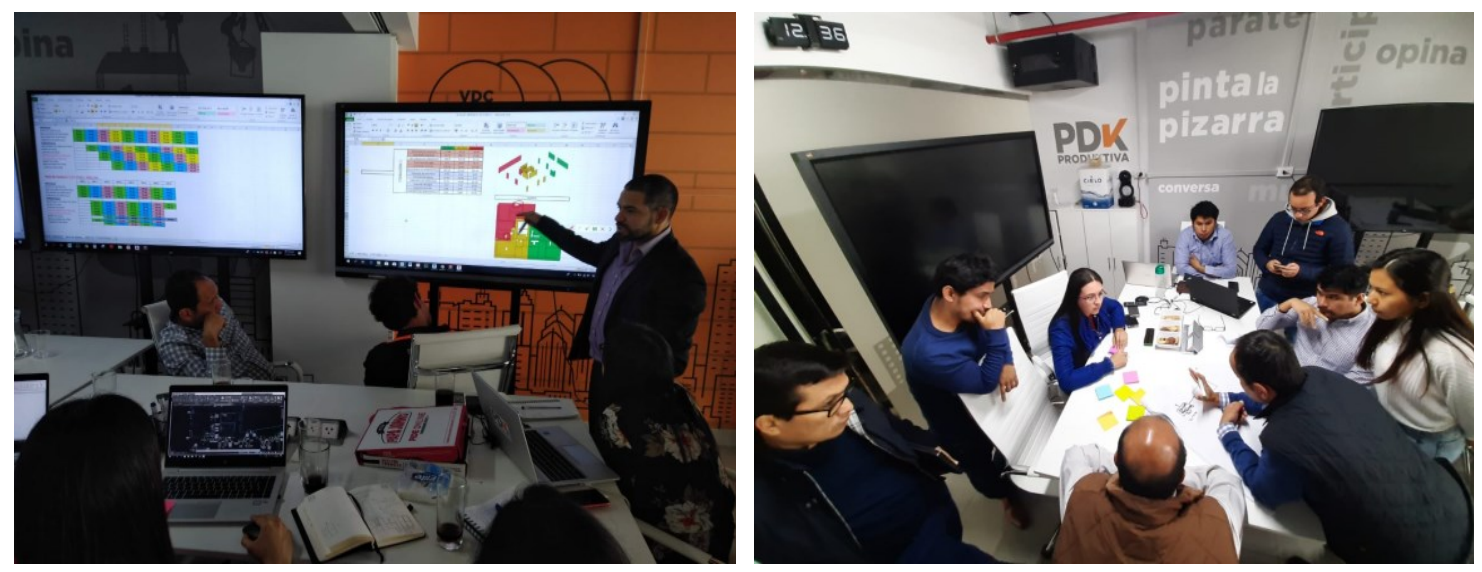

Figure 4: Photos of the work sessions of the integrated teams. The explanation of structure takt planning by the contractor is in the left photo and the Anchored walls integrated team on the right photo. 


\section{DISCUSSION}

The construction projects are very complex because of this it is necessary the participation of several specialists to achieve a project that adds value to the clients and that continuously seeks the efficiency of this. However, as explained, it is very difficult to achieve collaboration between the different organizations that participate in a project since each one looks after their own interests. Integrated team is a tool, which as explained in the case study, which plausibly helps to achieve the much desired collaboration between the parties. Project integration practices like team integration and co-location have shown great economic results for the project however, there is a result that has not been measured in the research: the degree of satisfaction of each of the participants for the best use of their time.

One of the advantages of project integration practices is that the estimation of the cost of the project is carried out from when the design is not very mature until when the design is ready for construction. This allows informed decisions to be made at cost, at meetings between designers, builder and owner. The fact of having used the indicated work model has shown great economic results for the project, however there is a result that has not been measured in the research: the degree of satisfaction of each of the participants for the best use of their time.

While it is true, integrated teams can be formed independently without using colocation tools. It is advisable to integrate both tools since placing the participants of a project in the same workplace increases collaboration (Kokkonen and Vaagaasar, 2018) and this is necessary for the integrated teams to work.

Visualizing the different design alternatives using BIM models also aided in rapid decision making. This was because the comparison between the amount of resources used in one alternative versus another was made in a matter of minutes. The present investigation on the influence of BIM technology on the way of working in integrated teams has not been studied in depth, but it could be a following investigation.

\section{CONCLUSIONS}

According to the case reviewed, the use of integrated team and co-location are tools that bring benefits to the projects. For example, in the case studied, it was possible to identify opportunities for improvement that were finally reflected in savings for the project. Similar findings like Tillmann, Berghede, Ballard and Tommelein (2014). It is also important to accompany the design alternatives with an adequate cost estimate for the project. The workplace contributes to the collaboration between the parties as it improves communication when the people of the teams face to face. This increases the speed of decision making.

The companies had an interesting learning process. Among the points that worked was the process of not judging the ideas of others, having a team moderator that promoted dialogue and exchange of ideas. However, there were also some difficulties. Having the structural specialist in several work teams, there were waiting times in some integrated teams for not having the complete team.

One of the questions that an independent investigation deserves is the cost process, the evaluation of alternatives, the approach of the goals by integrated team and the standard sequence of design that must be followed for a specific type of project. 


\section{ACKNOWLEDGMENTS}

Special thanks to Produktiva Contractor company, especially César Guzman-Marquina, General Manager, for being a faithful believer in the improvement of the industry through the application of recommended practices of lean construction and allocating the company's budget for infrastructure implementation and development. In addition, a special thanks to Jorge Miranda, Lean Consultant who supported the lean implementation in the projects and finally to Fernando Chavez for the relentless work leading the implementation and for the knowledge generated for the industry

\section{REFERENCES}

Alhava, O., Laine, E., and Kiviniemi, A. 2015. Intensive big room process for co-creating value in legacy construction projects. Journal of Information Technology in Construction, 20, 146-158.

Baiden, B. K., Price, A. D. F., and Dainty, A. R. J. 2006. The extent of team integration within construction projects. International Journal of Project Management, 24(1), 13-23. https://doi.org/10.1016/j.ijproman.2005.05.001

Dave, B., Pikas, E., Kerosuo, H., and Mäki, T. 2015. ViBR - Conceptualising a Virtual Big Room through the Framework of People, Processes and Technology. Procedia Economics and Finance, 21(15), 586-593. https://doi.org/10.1016/s22125671(15)00216-6

Fleming, Q. W., and Koppelman, J. M. 1996. Integrated project development teams: Another fad, or a permanent change. International Journal of Project Management, 14(3), 163-168. https://doi.org/10.1016/0263-7863(95)00068-2

Forgues, D., Koskela, L., and Lejeune, A. 2008. Breaking socio-cognitive barriers to value generation in integrated teams. Proceedings of IGLC16: 16th Annual Conference of the International Group for Lean Construction, Manchester, UK, 1(514), 435-446.

Hagedoorn, J., Lokshin, B., and Zobel, A. K. 2018. Partner Type Diversity in Alliance Portfolios: Multiple Dimensions, Boundary Conditions and Firm Innovation Performance. Journal of Management Studies, 55(5), 809-836. https://doi.org/10.1111/joms.12326

Hudson, B. 2006. Integrated Team Working: You Can Get it if you Really Want it: Part I. J. Integrated Care, 14(1), 13-21. https://doi.org/10.1108/14769018200600004

Khanzode, A., Fischer, M., and Reed, D. 2007. "Challenges and benefits of implementing virtual design and construction technologies for coordination of mechanical, electrical, and plumbing systems on large healthcare project". Image Rochester NY, 5(Vdc), 205-212. Retrieved from http://itc.scix.net/data/works/att/w78-2007-032107-Khanzode.pdf

Kokkonen, A., and Vaagaasar, A. L. 2018. "Managing collaborative space in multipartner projects". Construction Management and Economics, 36(2), 83-95. https://doi.org/10.1080/01446193.2017.1347268

Konchar, M., and Sanvido, V. 1998. "Comparison of U.S. project delivery systems". Journal of Construction Engineering and Management, 124(6), 435-444. https://doi.org/10.1061/(ASCE)0733-9364(1998)124:6(435)

Kron, C., and Von Der Haar, R. 2016. "Target costing for the development of office buildings". 24th Annual Conference of the International Group for Lean Construction,Boston, USA, 49(0), 43-52. 
Le Pennec, M., and Raufflet, E. 2018. "Value Creation in Inter-Organizational Collaboration: An Empirical Study". Journal of Business Ethics, 148(4), 817-834. https://doi.org/10.1007/s10551-015-3012-7

Lee, H. W., Tommelein, I. D., and Ballard, G. 2010. "Lean design management in an infrastructure design-build project: A case study. Challenging Lean Construction Thinking: What Do We Think and What Do We Know?" - 18th Annual Conference of the International Group for Lean Construction,Haifa, Israel 18, 113-122.

Ma, Z., Zhang, D., and Li, J. 2018. A dedicated collaboration platform for Integrated Project Delivery. Automation in Construction, 86(1) 199-209. https://doi.org/10.1016/j.autcon.2017.10.024

Majava, J., Haapasalo, H., and Aaltonen, K. 2019. "Elaborating factors affecting visual control in a big room". Construction Innovation, 19(1), 34-47. https://doi.org/10.1108/CI-06-2018-0048

Maslin-Prothero, S. E., and Bennion, A. E. 2010. "Integrated team working: A literature review". International Journal of Integrated Care, 10(2). https://doi.org/10.5334/ijic.529

Nicolini, D., Holti, R., and Smalley, M. 2001. "Integrating project activities: the theory and practice of managing the supply chain through clusters". Construction Management and Economics, 19(1), 37-47. https://doi.org/10.1080/014461901452067

Ochieng, E., and Price, A. D. 2009. "Framework for managing multicultural project teams". Engineering, Construction and Architectural Management, 16(6), 527-543. https://doi.org/10.1108/09699980911002557

Pargar, F., Kujala, J., Aaltonen, K., and Ruutu, S. 2019. "Value creation dynamics in a project alliance". International Journal of Project Management, 37(5), 716-730. https://doi.org/10.1016/j.ijproman.2018.12.006

Reed, D., Ashcraft, H., Khanzode, A., Fischer, M., Rischmoller, L., and Berg, P. 2017. "Integrating delivery of a large hospital complex". Proceedings of the 25th Annual Conference of the International Group for Lean Construction, Chenna, India, (July), 201-208. https://doi.org/10.24928/2017/0348

Smits, K., and van Marrewijk, A. 2012. "Chaperoning: practices of collaboration in the Panama Canal Expansion Program". International Journal of Managing Projects in Business, 5(3), 440-456. https://doi.org/10.1108/17538371211235317

Tezel, A., Aziz, Z., Koskela, L., and Tzortzopoulos, P. 2016. Visual management condition in highways construction projects in England. IGLC 2016 - 24th Annual Conference of the International Group for Lean Construction, 133-142.

Tillmann, P., Berghede, K., Ballard, G., and Tommelein, I. D. 2014. "Developing a production system on IPD: Considerations for a pluralistic environment". 22nd Annual Conference of the International Group for Lean Construction: Understanding and Improving Project Based Production, Oslo, Norway, 1(415), 317-328.

Zimina, D., Ballard, G., and Pasquire, C. 2012. "Target value design: using collaboration and a lean approach to reduce construction cost". Construction Management and Economics, 30(5), 383-398. https://doi.org/10.1080/01446193.2012.676658 
Influence of Integrated Teams and Co-location to Achieve the Target Cost in Building Projects

This paper was intentionally left blank. 